\title{
Milk Productivity of Holstein Breed of Different Selections in the Conditions of Uzbekistan
}

\author{
Ashirov Murodulla Eshonqulovich ${ }^{1 *}$ and Yuldashev Alo Askarovich ${ }^{2}$ \\ ${ }^{1}$ Academician of the Russian Academy of Natural Sciences, Professor of the Uzbek Livestock and Poultry Scientific Research Institute, Tajikistan \\ ${ }^{2}$ Doctoral candidate, Uzbek Livestock and Poultry Scientific Research Institute, Tajikistan
}

Submission: January 30, 2019; Published: February 27, 2019

*Corresponding author: Ashirov Murodulla Eshonqulovich, Academician of the Russian Academy of Natural Sciences, Doctor Agricultural Science, Professor of the Uzbek Livestock and Poultry Scientific Research Institute, Tashkent Region, Kibray District, Qizil Shalola Small Town, Tajikistan

\begin{abstract}
It was found that despite the selection, the Holstein cows have a high genetic potential of milk production and in all lactation, it is good in the specific conditions of the hot climate of Uzbekistan. The milk production level of German cows for the first lactation was $6511.2 \mathrm{~kg}$ of milk with a fat content of $3.84 \%$, the Dutch - $6653.0 \mathrm{~kg}$ with fat content of $3.95 \%$, and local breed $-6495.2 \mathrm{~kg}$ with a fat content of $3.95 \%$. All mature cows retained high milk production, for III lactation and older it was $7112.5 \mathrm{~kg}$ and $3.90 \%, 7266.0 \mathrm{~kg}$ and $3.90 \%, 6847.5 \mathrm{~kg}$ and $3.94 \%$, respectively. The yield of Dutch breeding cows was higher for I lactation by $141.80-157.8 \mathrm{~kg}$, for III lactation and older by $153.5-418.5 \mathrm{~kg}$, the yield of milk fat by 12.8-6.3 kg, respectively, of indicators peers of German and local selection. The cows of the studied selections combined well with high milk yield and fat content. The level of $4 \%$ milk for the studied lactation in all cows was quite high and testified to its good nutritional value. Holstein cows of different breeds are distinguished by a strong dairy type.
\end{abstract}

Keywords: Breed; Herd; Cows; Milk; Selection

\section{Introduction}

In the further development of animal husbandry, the improvement of breeding, productive, reproductive, technological qualities of breeding livestock, the creation of highly productive herds, increasing the volume of livestock production, widespread use of the genetic potential of productivity of the leading breeds of the world's gene pool is of relevance. Currently, the Holstein is the world's highest production dairy animal. Cows of this breed are distinguished by exceptionally high milk productivity, specific qualities of the udder, adaptation and various soil and climatic conditions, high feed allowance, dairy products and other valuable breeding characteristics [1-5]. In this regard, the study of the productive qualities of Holstein cows in relation with various factors is of great scientific and practical importance in the further improvement of their economically useful traits.

\section{Materials and Methods}

Three groups of mature cows were selected for research. The first group consisted of cows obtained from cows imported from Germany, in the second group - Holland ones and in the third group from local selection cows. In each group there were 20 cows. Studies have been conducted in the "Kuy Chirchik sut buloqi" breeding farm of the Low Chirchik district of the Tashkent region. Productive indicators of cows were studied by general received methods in zootechnics. Cows were kept in the same condition, nutrition was the same too, milk productiveness, a live mass as well as physiologic state were considered.

\section{Results}

The milk productivity is one of the main indicators assessing the breeding value of cows. Table 1 shows the milk productivity of cows for the first lactation. As seen from Table 1, cows of European breeding in the conditions of Uzbekistan showed a rather high potential for milk production. The level of milk yield in cows of group II was, respectively, 141.8 and $157.8 \mathrm{~kg}$, the yield of milk fat - by 12.8 and $6.3 \mathrm{~kg}$, the yield of $4 \%$ milk - by 319.1 and $155.8 \mathrm{~kg}$ higher, than cows I and III groups. For every $100 \mathrm{~kg}$ of body weight, cows of group I produced 106.5 and 19.0 $\mathrm{kg}$ of milk more than peers of groups II and III. We studied the productivity of cows and for II lactation (Table 2). 
Table 1: Milk productivity and body weight of cows per I lactation.

\begin{tabular}{|c|c|c|c|c|c|c|}
\hline \multirow{3}{*}{ Indicators } & \multicolumn{6}{|c|}{ Groups } \\
\hline & \multicolumn{2}{|l|}{$\mathbf{I}$} & \multicolumn{2}{|l|}{ II } & \multicolumn{2}{|c|}{ III } \\
\hline & $\bar{X} \pm s \bar{x}$ & Cv. \% & $\bar{X} \pm s \bar{x}$ & Cv. \% & $\bar{X} \pm s \bar{x}$ & Cv. \% \\
\hline Milk yield (kg) & $6511.2 \pm 106.9$ & 7.16 & $6653.0 \pm 110.2$ & 7.22 & $6495.2 \pm 85.5$ & 5.74 \\
\hline Fat content in milk (\%) & $3.84 \pm 0.02$ & 1.36 & $3.95 \pm 0.014$ & 1.54 & $3.95 \pm 0.01$ & 1.53 \\
\hline Milk fat yield (kg) & $250.0 \pm 4.78$ & 8.37 & $262.8 \pm 3.95$ & 6.63 & $256.5 \pm 2.63$ & 4.47 \\
\hline $4 \%$ fat-corrected milk (kg) & $6250.7 \pm 110.0$ & 7.67 & $6569.8 \pm 100.0$ & 6.61 & $6414.0 \pm 65.1$ & 4.43 \\
\hline Yield of $4 \%$ milk per $100 \mathrm{~kg}$ of body weight $(\mathrm{kg})$ & $1214.9 \pm 103.2$ & 7.5 & $1142.8 \pm 98.9$ & 6.8 & $1230.6 \pm 68.7$ & 4.9 \\
\hline Live weight (kg) & $514.5 \pm 11.7$ & 9.88 & $574.0 \pm 18.8$ & 14.3 & $521.2 \pm 11.3$ & 9.49 \\
\hline
\end{tabular}

Table 2: Milk productivity and body weight of cows per II lactation.

\begin{tabular}{|c|c|c|c|c|c|c|}
\hline \multirow[b]{3}{*}{ Indicators } & \multicolumn{6}{|c|}{ Groups } \\
\hline & \multicolumn{2}{|l|}{ I } & \multicolumn{2}{|l|}{ II } & \multicolumn{2}{|c|}{ III } \\
\hline & $\bar{X} \pm s \bar{x}$ & Cv. \% & $\bar{X} \pm s \bar{x}$ & Cv. \% & $\bar{X} \pm s \bar{x}$ & Cv. \% \\
\hline Milk yield (kg) & $6867.5 \pm 83.8$ & 5.32 & $6860.0 \pm 97.6$ & 6.20 & $6698.5 \pm 67.5$ & 4.39 \\
\hline Fat content in milk (\%) & $3.90 \pm 0.02$ & 2.27 & $3.94 \pm 0.03$ & 3.13 & $3.92 \pm 0.02$ & 2.16 \\
\hline Milk fat yield (kg) & $267.8 \pm 3.90$ & 6.34 & $270.3 \pm 4.35$ & 7.02 & $261.2 \pm 2.93$ & 4.86 \\
\hline $4 \%$ fat-corrected milk $(\mathrm{kg})$ & $6695.0 \pm 97.6$ & 6.34 & $6757.1 \pm 108.8$ & 7.02 & $6531.0 \pm 73.2$ & 4.86 \\
\hline Yield of $4 \%$ milk per $100 \mathrm{~kg}$ of body weight $(\mathrm{kg})$ & $1265.8 \pm 68.1$ & 24.4 & $1166.2 \pm 28.5$ & 10.8 & $1240.2 \pm 23.7$ & 8.37 \\
\hline Live weight (kg) & $528.9 \pm 11.2$ & 9.22 & $579.4 \pm 30.4$ & 23.2 & $540.1 \pm 9.2$ & 7.84 \\
\hline
\end{tabular}

In lactation II, milk yield and milk fat yield in groups I and II were characterized by similar rates and they exceeded milk yield by 169 and $161.5 \mathrm{~kg}$, respectively, and milk yield by 6.6 and $9.1 \mathrm{~kg}$ of cows of group III. The yield of $4 \%$ milk in cows I and II groups were 164 and $226.1 \mathrm{~kg}$ higher than the peers of group III. We continued to study the dynamics of milk production of cows in the context of lactation (Table 3). Analysis of the data in Table 3 shows that the yield of cows of group II is 153.5 and $418.5 \mathrm{~kg}$ (P $<0.01)$, the yield of milk fat is 5.9 and $13.5 \mathrm{~kg}$, $(\mathrm{P}<0.05)$, milk yield
$4 \%$ milk - by 149.7 and 339, $6 \mathrm{~kg}(\mathrm{P}<0.05)$, body weight - 62 and $59 \mathrm{~kg}$ higher than that of groups I and III cows. The highest yield of $4 \%$ milk per $100 \mathrm{~kg}$ of body weight was observed in the group I of cows, which produced $100 \mathrm{~kg}$ of body weight, respectively, by $113.6(\mathrm{P}>0.01)$ and $53.1 \mathrm{~kg}$ more than their peers of II and III groups. The yield of I, II and III groups of cows for III lactation as compared with I lactation increased respectively by 601.3 $\mathrm{kg}$ (9.23\%), by $613.0 \mathrm{~kg}(9.21 \%), 352.3 \mathrm{~kg}(5.42 \%)$ and they showed a high genetic potential of milk production.

Table 3: Milk productivity and body weight of cows per III and older lactation.

\begin{tabular}{|c|c|c|c|c|c|c|}
\hline \multirow[b]{3}{*}{ Indicators } & \multicolumn{6}{|c|}{ Groups } \\
\hline & \multicolumn{2}{|l|}{ I } & \multicolumn{2}{|l|}{ II } & \multicolumn{2}{|c|}{ III } \\
\hline & $\bar{X} \pm s \bar{x}$ & Cv. \% & $\bar{X} \pm s \bar{x}$ & Cv. \% & $\bar{X} \pm s \bar{x}$ & Cv. \% \\
\hline Milk yield (kg) & $7112.5 \pm 68.1$ & 5.32 & $7266.0 \pm 53.9$ & 3.23 & $6847.5 \pm 147.7$ & 4.39 \\
\hline Fat content in milk (\%) & $3.90 \pm 0.02$ & 2.27 & $3.90 \pm 0.017$ & 1.86 & $3.94 \pm 0.014$ & 2.16 \\
\hline Milk fat yield (kg) & $277.4 \pm 2.91$ & 6.34 & $283.3 \pm 2.17$ & 3.33 & $269.8 \pm 5.77$ & 4.86 \\
\hline $4 \%$ fat-corrected milk (kg) & $6934.7 \pm 72.7$ & 4.57 & $7084.4 \pm 54.2$ & 3.32 & $6744.8 \pm 144.4$ & 9.32 \\
\hline Yield of $4 \%$ milk per $100 \mathrm{~kg}$ of body weight $(\mathrm{kg})$ & $1347.8 \pm 33.5$ & 11.32 & $1234.2 \pm 26.7$ & 9.81 & $1294.7 \pm 32.3$ & 11.34 \\
\hline Live weight (kg) & $543.5 \pm 13.6$ & 10.9 & $605.5 \pm 17.4$ & 12.5 & $546.1 \pm 10.2$ & 8.14 \\
\hline
\end{tabular}




\section{Conclusion}

a. The Holstein breed of the European selection have a high genetic potential of milk production and are distinguished by the ability to display it quite high in the specific conditions of the hot climate of Uzbekistan.

b. The Holstein breed of different selections combines well with high milk yield and fat content. Holstein breed of different breeds are distinguished by a strong dairy type.

\section{References}

1. Zavertyaev B, Prokhorenko P (2000) Improvement of the breeding and selection system of dairy cattle. Moscow. Journal of Zootechniya, 8: 8-12.
2. Yanchukov I, Matveeva E, Lavrukhina A (2011) Horizons in selection of dairy cattle. Journal of Dairy and Beef Cattle Farming, Moscow, Russia, 1: $10-11$.

3. Egiazaryan A, Prokhorenko P, Saxa E (2009) Genetic progress on economically useful signs at improvement of the Leningrad type of black-and-white cattle. Journal of Zootechniya, Moscow, Russia, 4: 2-4

4. Ashirov M (2017) Selection of milky cattle. Tashkent. Monograph, pp. 380

5. Ashirov M, Yuldashev A (2018) Productive properties of Holstein breed of different selections. Journal of Dairy and Beef Cattle Farming, Mosco, Russia, 7: 27-29. 